\title{
PERBANDINGAN HASIL BELAJAR ANTARA MODEL PEMBELAJARAN MAKE A MATCH DAN SCRAMBLE
}

\author{
Rizki Nikmatinafiah ${ }^{1}$, Syafdi Maizora ${ }^{2}$, Nurul Astuty Yensy B. ${ }^{3}$ \\ 1,2,3 Program Studi Pendidikan Matematika JPMIPA FKIP Universitas Bengkulu \\ Email :'rizkinikmatinafiah20@gmail.com, ${ }^{2}$ syafdiichiemaizora@unib.ac.id, \\ ${ }^{3}$ nurulastutyyensy@yahoo.com
}

\begin{abstract}
ABSTRAK
Penelitian ini bertujuan untuk mengetahui perbandingan model pembelajaran kooperatif tipe Make A Match dengan model pembelajaran kooperatif tipe Scramble di kelas VII SMP Negeri 22 Kota Bengkulu. Populasi pada penelitian ini adalah siswa kelas VII SMP Negeri 22 Kota Bengkulu, sedangkan sampelnya yaitu siswa kelas VII A sebagai kelas eksperimen 1 dengan menerapkan pembelajaran Make A Match dan siswa kelas VII B sebagai kelas eksperimen 2 dengan menerapkan model pembelajaran Scramble. Analisis data menggunakan uji-t dengan data berdistribusi normal dan homogen. Berdasarkan hasil penelitian diperoleh nilai rata-rata siswa yang diajar dengan menggunakan Make A Match lebih tinggi dibandingkan dengan nilai rata-rata siswa yang diajar dengam menggunakan Scramble. Dari hasil penelitian diketahui hasil uji-t dengan $t_{\text {hitung }}(3,28)>t_{\text {tabel }}(0,423)$. Nilai thitung yang diperoleh lebih dari nilai $t_{\text {tabel }}$ maka dapat disimpulkan bahwa terdapat Perbandingan Hasil Belajar Siswa Antara Model Pembelajaran Kooperatif Tipe Make A Match dan Tipe Scramble di Kelas VII SMP Negeri 22 Kota.
\end{abstract}

Kata Kunci : Penelitian Kuasi-ekperimen, Model Pembelajaran Make A Match dan Sramble

\begin{abstract}
This research aimed to know the comparison learning Make A Match with learning model Scramble on the study's result of mathematics for student grade VII SMP Negeri 22 Kota Bengkulu. This research population was students grade VII SMP Negeri 22 Kota Bengkulu where as the sample was student grade VII A as first experiment class by applying Scramble learning and student grade VII B as second experiment class by applying learning Scramble. Data analysis use t-test with normal and homogenous distribution data. Based on the research result, the average score of students who taught using Make A Match was higher than the average score of students taught by using Scramble. From result of research known result of $t$-test with $t_{\text {count }}(3,28)>t_{\text {tabel }}(0,423)$. $t_{\text {count }}$ value obtained more than $t_{\text {table }}$ then it can be concluded that there was Comparison of Student Learning Outcomes Between Cooperative Learning Model Type Make A Match and Type Scramble for grade VII SMP Negeri 22 Kota.

Keywords: Quasi-Experimental Research, Learning model Comparison Make A Match and Sramble
\end{abstract}

Rizki Nikmatinafiah, Syafdi Maizora, Nurul Astuty Yensy B.

Perbandingan Hasil Belajar antara Model Pembelajaran Make a Match dan Scramble 


\section{PENDAHULUAN}

Matematika merupakan salah satu mata pelajaran yang wajib diajarkan pada semua jenjang pendidikan, baik pendidikan dasar, menengah dan tinggi. Dalam kehidupan sehari-hari matematika memegang peran yang penting. Matematika berfungsi dalam mengembangkan kemampuan mengukur, menghitung dan menggunakan rumus dalam kehidupan sehari-hari.

Permasalahan matematika menjadi persoalan penting bagi proses pendidikan. Pada pembelajaran matematika SMP sering dijumpai peserta didik yang mengalami kesulitan dalam memahami materi yang diajarkan. Kesulitan memahami materi dapat disebabkan oleh faktor internal (dari dalam diri peserta didik) dan faktor eksternal (dari luar diri peserta didik).

Hasil wawancara yang dilakukan dengan ibu Syntha yang merupakan salah satu guru mata pelajaran matematika kelas VII di SMP Negeri 22 Kota Bengkulu, kelas VII telah menerapkan kurikulum 2013 Menurut ibu Syntha target yang ingin dicapai adalah semua nilai peserta didik mencapai kriteria ketuntasan minimal. Selain itu berdasarkan hasil wawancara juga terdapat beberapa kendala dalam proses pembelajaran matematika diantaranya kurang aktifnya peserta didik dalam proses pembelajaran didalam kelas, peserta didik hanya mengandalkan pengetahuan yang diberikan oleh guru tanpa ada proses berpikir sehingga pembelajaran lebih berpusat pada guru. Proses pembelajaran yang kurang menarik manjadi salah satu faktor permasalahan pembelajaran matematika.

Pemilihan model pembelajaran merupakan salah satu hal yang paling penting, ada begitu banyak model yang dapat diterapkan dalam proses pembelajaran salah satunya yaitu model pembelajaran kooperatif. Model pembelajaran kooperatif adalah suatu model pembelajaran yang mana peserta didik dibagi kedalam kelompokkelompok kecil yang heterogen sehingga peserta didik tersebut harus saling membantu dalam memahami bahan pelajaran (Rusman,2014:209). Kurang aktifnya peserta didik dalam proses pembelajaran dikelas mengharuskan guru untuk melakukan suatu tindakan agar peserta didik tersebut dapat ikut berperan aktif dalam proses pembelajaran. Pemilihan model yang tepat menjadi komponen yang penting agar dapat mencapai tujuan pembelajaran yang di inginkan. Model pembelajaran kooperatif tipe Make A Match adalah salah satu model pembelajaran yang sangat tepat dilakukan untuk mengatasi peserta didik yang kurang aktif.

Model pembelajaran kooperatif tipe Make A Match merupakan model pembelajaran yang dapat meningkatkan keaktifan peserta didik. Karakteristik model pembelajaran Make A Match memiliki hubungan yang erat dengan karakteristik siswa yang gemar bermain (Shoimin, 2014: 98). Kelebihan menggunakan model pembelajaran Make A Match salah satunya adalah dapat meningkatkan aktivitas belajar siswa, baik secara kognitif maupun fisik. Kekurangan dari model pembelajaran ini 
yaitu jika dilakukan secara terus menerus akan menimbulkan kebosanan, sehingga untuk mengatasi hal tersebut guru perlu menerapkan model pembelajaran yang lain salah satunya model pembelajaran kooperatif tipe Scramble.

Model pembelajaran kooperatif tipe Scramble merupakan model pembelajaran dengan membagikan lembar soal dan lembar jawaban yang disertai dengan alternatif jawaban yang tersedia. Melalui pembelajaran Scramble siswa dapat dilatih menyusun kata, kalimat, atau wacana yang acak susunanya dengan susunan yang bermakna dan mungkin lebih baik dari susunan aslinya (Shoimin 2014 :166). Kelebihan dari Model pembelajaran Scramble yaitu melatih peserta didik untuk belajar mengerjakan soal dengan jawaban acak sehingga peserta didik dapat berpikir.

Uraian penjabaran tersebut, dapat disimpulkan bahwa model pembelajaran kooperatif tipe Make A Match dan Scramble dapat digunakan untuk mengatasi masalah peserta didik yaitu kurang aktif dalam proses pembelajaran.

\section{METODE PENELITIAN}

Populasi dalam penelitian ini adalah seluruh siswa kelas VII semester genap SMPN 22 Kota Bengkulu tahun pelajaran 2017/2018 yang terdiri dari empat kelas yaitu kelas VII A sampai dengan VII D. Pengambilan sampel dilakukan dengan menggunakan teknik cluster sampling dengan menentukan dua kelas yang memiliki kemampuan awal yang relatif sama berdasarkan data nilai ujian terakhir siswa dengan melihat nilai rata-ratanya pada kelas VII A sampai VII B sehingga diperoleh kelas yang memiliki kemampuan awal yang relatif sama adalah kelas VII A dan VII B. Sampel dalam penelitian ini adalah kelas VII A dan VII B. Penelitian ini merupakan penelitian quasi eksperimen. Desain yang digunakan dalam penelitian ini adalah nonequivalent group posttest only design karena sampel memiliki kemampuan awal yang relatif sama. Data dalam penelitian ini adalah data kuantitatif yang berupa data hasil belajar yang diperoleh dari nilai postest setelah pembelajaran. Tes yang telah disusun harus memenuhi validitas tes. Setelah intrumen tes dinyatakan valid oleh guru dan dosen, tes tersebut diujicobakan di luar sampel penelitian yaitu pada kelas VII C. Intrumen yang digunakan berbentuk soal essay 6 soal. Untuk menguji validitas item tes digunakan rumus koefisien korelasi product moment dengan rumus :

$$
r_{x y}=\frac{N \sum x y-\left(\sum x\right)\left(\sum y\right)}{\sqrt{\left.\left\{\left(N\left(\sum x^{2}\right)-\left(\sum x\right)^{2}\right)\left(N\left(\sum y^{2}\right)-\sum y\right)^{2}\right)\right\}}}
$$

(Jakni, 2016:165)

Dengan kriteria:

Jika $r_{x y}>r_{\text {tabel }}$ maka soal valid

Jika $r_{x y}<r_{\text {tabel }}$ maka soal tidak valid. Selanjutnya Uji Reliabilitas tes hasil belajar dapat dihitung menggunakan rumus :

$$
r_{11}=\left[\frac{k}{k-1}\right]\left[1-\frac{\sum s \sigma_{h}^{2}}{\sigma_{t}^{2}}\right]
$$

(Syofian Siregar, 2014:176)

Instrumen/soal dapat digunakan sebagai instrument dalam penelitian jika nilai koefisien korelasi berada di kategori sedang, (Lestari dan Yudhanegara, 2017 : 214). 
Setelah dilakukan uji reliabilitas maka dilakukan uji pembeda (DP) pada masing masing butir soal di tentukan dengan menggunakan rumus :

$$
D P=\frac{\bar{X}_{A}-\bar{X}_{B}}{S M I}
$$

(Lestari dan Yudhanegara, 2017:223-217)

\section{Pengujian Persyaratan Analisis Uji Normalitas}

Rumus yang digunakan untuk menguji hipotesis adalah rumus chi kuadrat yaitu :

$$
\chi_{0}^{2}=\sum_{i=1}^{k} \frac{\left(f_{0}-f_{h}\right)^{2}}{f_{h}}
$$

(Sugiyono, 2012:19)

Kriteria pengujiannya adalah $\mathrm{H}_{0}$ diterima jika $X_{\text {hitung }}^{2} \leq X_{\text {tabel }}^{2}$. Sebaliknya $\mathrm{H}_{0}$ ditolak jika $X_{\text {hitung }}^{2}>X_{\text {tabel }}^{2}$. Dengan taraf nyata $5 \%$ $(\propto=0,05)$, Sugiyono $(2017: 109)$

\section{Uji Homogenitas}

Uji homogenitas dilakukan untuk mengetahui apakah kedua kelas mempunyai varians yang tidak jauh berbeda,

Untuk melakukan uji homogenitas varians menggunakan rumus uji fisher:

$$
F=\frac{\text { varians terbesar }}{\text { varians terkecil }}
$$

(Jakni, 2017:175)

Kriteria pengujiannya adalah $\mathrm{H}_{0}$ diterima jika $F_{\text {hitung }}<F_{\text {tabel }}$. Sebaliknya $\mathrm{H}_{0}$ ditolak jika $F_{\text {hitung }} \geq F_{\text {tabel }}$, dengan taraf nyata $5 \% \quad(\propto=0,05), \quad \mathrm{dk}$ pembilang $=$ $\left(n_{b}-1\right)$ dan dk penyebut $=\left(n_{k}-1\right)$.

\section{Pengujian Hipotesis}

Data yang telah diperoleh dianalisis dengan uji hipotesis menggunakan uji-t untuk sampel independen. Adapun rumusnya sebagai berikut:

$$
t=\frac{X_{1}-X_{2}}{\sqrt{\frac{S_{1}^{2}}{n_{1}}+\frac{S_{2}^{2}}{n_{2}}}}
$$

\section{HASIL DAN PEMBAHASAN}

\section{Hasil}

Berdasarkan pendapat Sudijono, nilai $r_{11}$ memenuhi kriteria tinggi karena koefisien reliabilitasnya lebih dari 0,70. Oleh karena itu instrumen tes pemahaman konsep matematis tersebut sudah layak digunakan untuk mengumpulkan data.

Analisis yang dilakukan untuk menguji hipotesis adalah dengan menggunakan uji normalitas dan uji homogenitas dengan hasil sebagai berikut:

Tabel 1. Uji Chi-Square

\begin{tabular}{|ccccc|}
\hline Kelas & $\chi_{\text {hitung }}^{2}$ & $\chi_{\text {tabel }}^{2}$ & Kesimpulan & Keterangan \\
\hline Eksperimen 1 & 2,050 & 11,070 & $H_{0}$ diterima & $\begin{array}{c}\text { Data } \\
\text { berdistribusi } \\
\text { normal }\end{array}$ \\
\hline Eksperimen 2 & 4,631 & 11,070 & $H_{0}$ diterima & $\begin{array}{c}\text { Data } \\
\text { berdistribusi } \\
\text { normal }\end{array}$ \\
\hline
\end{tabular}

Berdasarkan tabel 1 di atas, dapat disimpulkan bahwa data kemampuan pemahaman konsep matematis siswa pada kelas eksperimen dan kelas kontrol berdistribusi normal. Karena sampel berdistribusi normal, maka dilanjutkan dengan menggunakan uji homogenitas 
variansi. Uji homogenitas variansi dilakukan untuk mengetahui apakah kedua kelompok data memiliki variansi yang homogen atau tidak.

Selanjutnya pengujian hipotesis dengan menggunakan uji-t. Karena data normal dan homogen maka dilanjutkan dengan melakukan uji hipotesis. Uji hipotesis yang digunakan adalah uji kesamaan dua rata-rata. Analisis data menggunakan uji-t, yaitu uji satu pihak.

Tabel 2 Hasil Uji t

\begin{tabular}{|ccc|}
\hline $\boldsymbol{t}_{\text {hitung }}$ & $\boldsymbol{F}_{\text {tabel }}$ & Kesimpulan \\
\hline 3,284 & 2,03 & $H_{0}$ ditolak \\
\hline
\end{tabular}

Berdasarkan tabel 2 dapat dilihat bahwa $t_{\text {hitung }}>F_{\text {tabel }}$ yaitu 3,284 $>2,03$, sehingga berdasarkan kriteria pengujian $H_{0}$ ditolak. Jadi dapat diketahui bahwa Ratarata hasil belajar matematika siswa pada kelas Make A Match lebih dari rata-rata hasil belajar matematika siswa pada kelas Scramble.

\section{PEMBAHASAN}

Pada penelitian ini, kelas eksperimen 1 yang menggunakan model pembelajaran kooperatif tipe Make A Match dan kelas eksperimen 2 yang menggunakan model pembelajaran Kooperatif tipe Scramble. Kedua model digunakan untuk mencapai tujuan pembelajaran.

Proses pembelajaran pada kedua kelas eksperimen, peneliti menggunakan lembar kerja peserta didik (LKPD) berbasis saintifik sebagai bahan pelajar. Hal ini sesuai dengan Kurikulum SMP Negeri 22 Kota Bengkulu yang mana telah menerapkan kurikulum 2013. Pembelajaran pada kelas eksperimen 1 dan kelas eksperimen 2 melibatkan siswa secara langsung sehingga menjadikan siswa aktif.

Sependapat dengan Huda (2012: 135) yang mengatakan bahwa Make A Match merupakan salah satu pendekatan konseptual yang mengajarkan siswa memahami konsepkonsep secara aktif, kreatif, efektif, interaktif, dan menyenangkan bagi siswa sehingga konsep mudah dipahami dan bertahan lama dalam struktur kognitif siswa. Pada kelas eksperimen 1 yaitu kelas VII A yang menggunakan model kooperatif tipe Make A Match. Peneliti membagikan kelompok mejadi enam kelompok dimana kelas VII A terdiri dari 24 peserta didik, sehingga dalam satu kelompok terdiri dari empat orang. Setelah kelompok dibentuk, peneliti membagikan lembar kerja peserta didik (LKPD) Masing- masing kelompok. Lembar kerja peserta didik merupakan penunjang dalam proses pembelajaran yang mana berguna agar peserta didik dapat menemukan sifat-sifat segiempat tanpa harus diberi tahu.

Lembar kerja peserta didik di kelas eksperimen 1 yang telah dibagian akan di diskusikan dengan anggota kelompok masing- masing dan setiap kelompok harus mempersiapkan dan mempertanggungjawabkan hasil kerjanya lalu tahap selanjutnya adalah setiap kelompok mempersentasikan laporan akhir.

Sama hal nya dengan kelas ekperimen 1, pada kelas eksperimen 2 yaitu kelas VII B yang menggunakan model kooperatif tipe Scramble. Peneliti membagikan kelompok mejadi enam kelompok dimana kelas VII B terdiri dari 23 peserta didik, sehingga dalam satu kelompok terdiri dari empat orang dan 
ada satu kelompok yang terdiri dari tiga orang. Setelah kelompok dibentuk, peneliti membagikan lembar kerja peserta didik (LKPD) Masing- masing kelompok. Lembar kerja peserta didik merupakan penunjang dalam proses pembelajaran yang mana berguna agar peserta didik dapat menemukan sifat-sifat segiempat tanpa harus diberi tahu.

Lembar kerja peserta didik di kelas eksperimen 2 yang telah dibagian akan di diskusikan dengan anggota kelompok masing- masing dan setiap kelompok harus mempersiapkan dan mempertanggungjawabkan hasil kerjanya lalu tahap selanjutnya adala setiap kelompok mempersentasikan laporan akhir.

Setelah kelompok mempersentasikan hasilnya, peneliti akan memberikan penghargaan kepada kelompok yang dapat menemukan konsep sifat-sifat segiempat yang paling tepat dan bersama-sama dengan peserta didik guru meyebutkan kembali sifat-sifat segiempat.

Tahap selanjutnya ialah peneliti memberikan kartu-kartu soal dan kartu jawaban, disinilah perbedaa kelas ekperimen 1 dan kelas eksperimen 2 terlihat. Pada kelas eksperimen 1, tiga kelompok akan diberikan kartu soal dan 3 kelompok lagi akan diberikan kartu jawaban. Kartu soal terdiri dari 4 soal begitu juga dengan kartu jawaban. Peneliti memberikan waktu kepada peserta didik untuk memilih kartu soal / kartu jawaban dengan cara menggunting terlebih dahulu kartu soal/ jawaban, kemudian kartu di gulung dan peserta didik memilih kartu lalu membukanya. Peneliti memberikan waktu kepada peserta didik untuk memikirkan kemungkinankemungkinan yang sesuai dengan pasangan kartu yang peserta didik pegang.

Pada kelas eksperimen 1, peserta didik bersifat individu dimana tidak bisa mencocokan kartu secara berkelompok melainkan secara individu, sehingga peserta didik dituntut lebih aktif dan mengerti dengan materi yang diajarkan agar dapat mencari pasangan yang sesuai. Tahap selanjutnya yaitu ketika peserta didik telah menemukan pasangan kartu yang cocok.

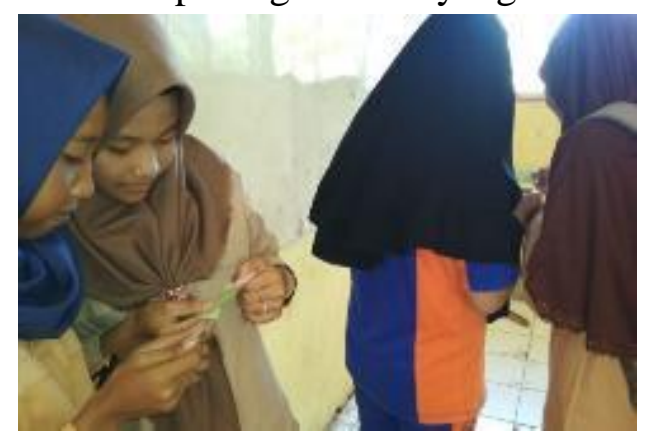

\section{Gambar 1. Mencari Pasangan Kartu Kelas Ekspeimen 1}

Pasangan segera melaporkan kepada peneliti dan jika benar akan diberikan nilai. Setelah itu peneliti mempersilahkan pasangan yg benar untuk mempersentasikan hasilnya. 


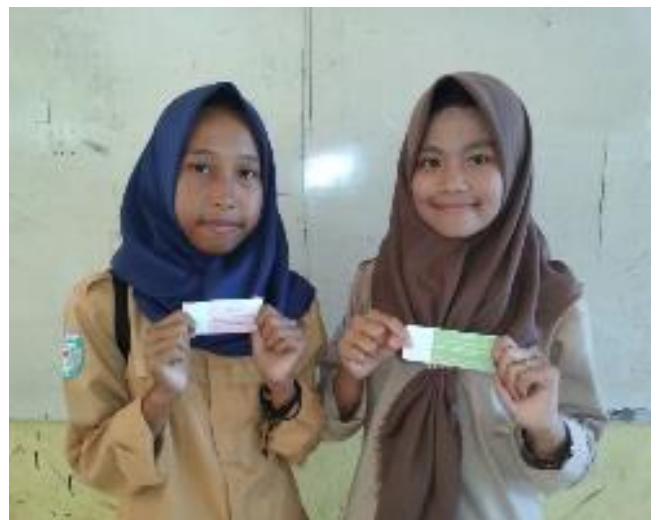

Gambar 2. Mempresentasikan Pasangan Kartu Kelas Ekspeimen 1

Sama halnya dengan kelas eksperimen 1, pada kelas eksperimen 2 yaitu kelas VII B yang menggunakan model pembelajaran Scramble peneliti juga membagikan kartu soal dan kartu jawaban, akan tetapi pada kelas eksperimen 2, setiap kelompok mendapatkan kartu jawaban dan kartu soal berbeda halnya dengan kelas eksperimen 1 yang masing- masing kelompok hanya mendapatkan satu jenis kartu.Sependapat dengan Shoimin (2014: 166) berpendapat bahwa istilah Scramble berasal dari Bahasa Inggris yang diterjemahkan dalam Bahasa Indonesia berarti perbuatan pertarungan dan perjuangan. Scramble merupakan model pembelajaran yang mengajak siswa untuk menemukan jawaban dan menyelesaikan permasalahan yang ada dengan cara membagikan lembar soal dan lembar jawaban yang disertai dengan alternatif jawaban yang tersedia. Kartu soal pada kelas eksprimen 2 terdiri dari 6 soal sedangkan kartu jawaban terdiri dari 12 kartu.

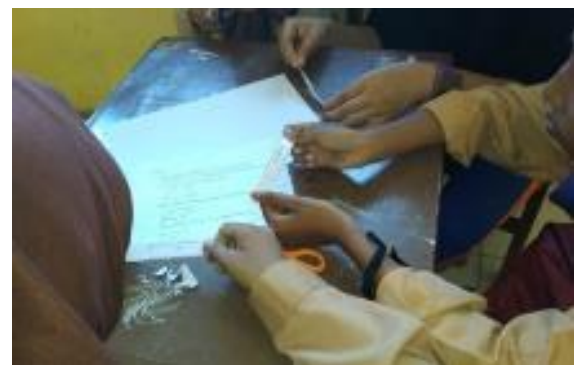

Gambar 3. Mecocokan Kartu Kelas Ekspeimen 2

Tahap selanjutnya pada kelas eksperimen 2, masing-masing kelompok mencocokan soal dengan kartu jawaban yang mereka miliki secara berkelompok yang mana berbeda dengan kelas eksperimen 1 yang mencocokan kartu secara individu. Setelah kartu jawaban dan kartu soal dicocokan kelompok memberitahukan kepada peneliti agar dapat diperi nilai. Tahap selanjutnya peneliti memanggil kelompok yang dapat mencocokkan kartu dengan benar untuk mempersentasikan kepada peserta didik yang lain.

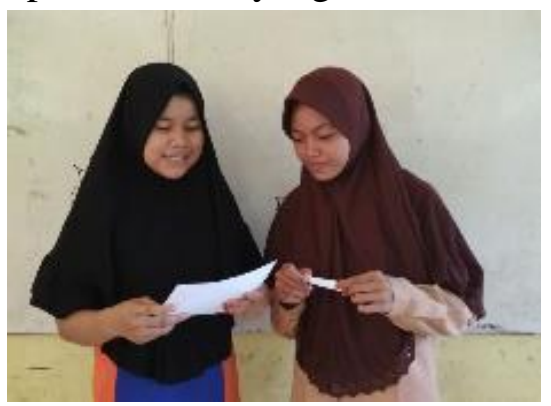

Gambar 4. Mempresentasikan Hasil Diskusi Kelas Ekspeimen 2

Pada kedua proses pembelajaran baik pada kelas eksperimen 1 maupun kelase eksperimen 2, setiam model memiliki kekurangan dan kelebihan akan tetapi pada kelas eksperimen 1 dimana kelas yang menggunakan model pembelajaran koopertif 
tipe Make A Match memiliki lebih banyak kelebihan. Peserta didik pada kelas eksperimen 1 mengikuti proses pembelajaran dengan sangat baik dikarnakan peneliti telah menjelaskan bahwa akan ada proses individu yaitu mencari pasangan kartu yang tidak di perbolehkan diskusi lagi dengan kelompoknya masing-masing sedangkan pada kelas eksperimen 2 peserta ddik mencocokan soal dan jawaban secara bersama-sama sehingga banyak peserta didik yang diam saja dan hanya menunggu jawaban dari kelompoknya saja.

Dari hasil analisis proses belajar kedua kelas eksperimen, diketahui bahwa model pembelajaran kooperatif tipe Make A Match lebih efektif dibandingkan model pembelajaran kooperatif tipe Scramble. Nilai rata-rata kelas yang menggunakan model pembejaran kooperatif tipe Make A Match lebih tinggi dibandingkan kelas yang menggunakan model pembelajaran kooperatif tipe Scramble. Hal ini disebabkan beberapa hal berikut: (1)Pada kelas Make A Match kartu dicocokan secara individu sehingan setiap peserta didik memiliki pengalaman belasar indivu tanpa mengandalak peserta didik yang lain. (2) Adanya tahap yang tidak berjalan secara maksimal pada kelas Scramble, yakni pada tahap mencocokan kartu soal dan kartu jawaban, beberapa peserta didik tidak berperan aktif dalam mencocokan kartu dan hanya menunggu jawaban kelompok.

Berdasarkan analisis hasil penelitian, diperoleh bahwa hasil belajar matematika pada kelas eksperimen 1 lebih tinggi dari hasil belajar matematika pada kelas eksperimen 2, dengan nilai rata-rata kelas eksperimen 1 adalah 70,1 dan nilai rata-rata kelas eksperimen 2 adalah 57,47. Pada kelas eksperimen 1 dari 24 orang peserta didik yang mengikuti posttest terdapat 11 orang peserta didik yang memiliki nilai diatas kriteria ketuntasan minimal (KKM). Sedangkan pada kelas eksperimen 2 dari 23 orang peserta didik yang mengikuti posttest hanya tiga orang peserta didik yang memiliki nilai diatas KKM.

Hasil analisis data menunjukkan bahwa model pembelajaran kooperatif tipe Make A Match dapat meningkatkan hasil belajar peserta didik. Hal ini disebabkan karena terdapat kegiatan individu yaitu mencari pasangan sehingga setiap individu dituntut untuk menguasai materi agar pilihannya dapat dipertanggung jawabkan.

Berdasarkan rata-rata nilai siswa terlihat bahwa presentase peserta didik dalam menjawab semua soal yaitu kelas Make A Match lebih tinggi daripada kelas Scramble. Dapat disimpulkan bahwa terlihat jelas perbedaan jawaban posttest antara siswa kelas eksperimen 1 dan siswa kelas eksperimen 2. Kelas eksperimen 1 (VII A) yang menggunakan model pembelajaran kooperatif tipe Make A Match lebih banyak menjawab benar pada posttest baik secara keseluruhan maupun per-item soal dibandingkan kelas eksperimen 2 (VII B) yang menggunakan model pembelajaran Scramble.

Pada kelas Make A Match banyak peserta didik yang dapat menjawab dengan rinci pertanyaan pada soal post test . dimana pada soal post test terdapat pertanyaan yang

Rizki Nikmatinafiah, Syafdi Maizora, Nurul Astuty Yensy B.

Perbandingan Hasil Belajar antara Model Pembelajaran Make a Match dan Scramble 
mengaruskan peserta didik menebak nama bangun tersebut dan menentukan sifat dari bangun tersebut.

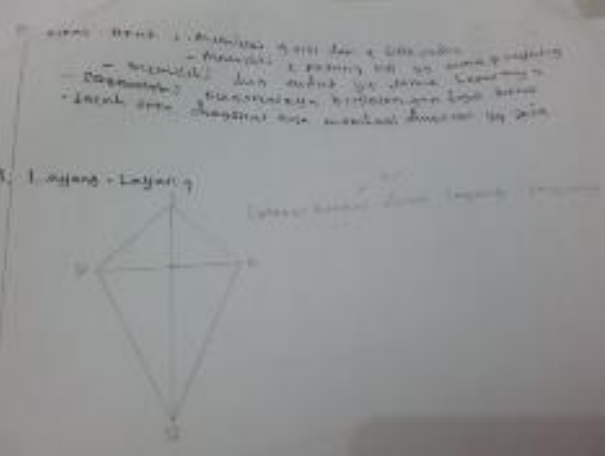

Gambar 5. Contoh Lembar Jawaban Postest Kelas Eksperimen 1

sedangkan pada kelas Scramble peserta didik hanya menjawab tanpa mengetahui konsep dari bangun datar itu sendiri.dan tidak dapat mengulang kembali sifat-sifat dari bangun datar yang dimaksud.

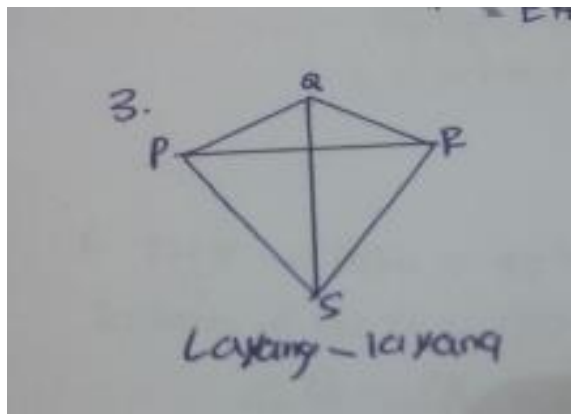

\section{Gambar 6. Contoh Lembar Jawaban Postest Kelas Eksperimen 2}

Jadi, dari rata-rata hasil belajar sisiwa dapat disimpilkan bahwa hasil belajar siswa yang diajar dengan model pembelajaran kooperatif tipe Make A Match lebih dari hasil belajar siswa yang diajar dengan model pembelajaran kooperatif tipe Scramble di kelas VII SMP Negeri 22 Kota Bengkulu.

\section{PENUTUP}

\section{Simpulan}

Hasil belajar siswa yang menggunakan model pembelajaran kooperatif tipe Make A Match lebih dari hasil belajar siswa yang menggunakan model pembelajaran kooperatif tipe Scramble pada pokok bahasan bangun datar segiempat dan segitiga di kelas VII SMP Negeri 22 Kota Bengkulu Dari hasil penelitian diketahui $t_{\text {hitung }}(3,28)>t_{\text {tabel }}(0,423)$. Karena Nilai $t_{\text {hitung }}$ yang diperoleh lebih dari nilai $t_{\text {tabel }}$ maka $\mathrm{H}_{0}$ ditolak

\section{Saran}

Berdasarkan hasil penelitian. Saran yang dapat diberikan oleh peneliti ialah : (1) Untuk guru agar dapat membuat kartu soal dan jawaban lebih kreatif sehingga peserta didik mendapatkan pengalaman belajar yang bermakna tanpa mengalami kesulitan. (2) Bisa digunakan untuk peneliti lainnya dengan modifikasi kartu soal dan jawaban sesuai dengan materi yang akan dipelajari dan kartu soal dan jawaban haruslah mudah dimengerti.

\section{DAFTAR PUSTAKA}

Arikunto, Suharsimi. 2010. Prosedur Penelitian Suatu Pendekatan Praktik. Jakarta: Rineka Cipta

Danim, Sudarwan. 2013. Pengantar Kependidikan. Bandung: Alfabeta

Dimyati dan Mudjiono. 2013. Belajar dan Pembelajaran. Jakarta: PT Rineka Cipta Huda, Miftahul. 2017. Model-model Pengajaran dan Pembelajaran. Yogyakarta: Pustaka Pelajar. 
Jakni. 2016. Metodologi Penelitian Eksperimen Bidang Pendidikan. Bandung: Alfabeta

Rusman. 2014. Model-model Pembelajaran. Jakarta: Raja Grafindo Persada

Shoimin, Aris. 2014. 68 Model Pembelajaran Inovatif dalam Kurikulum 2013. Yogyakarta: Arruzz Media

Siregar, Syofian. 2014. Statistika Deskriptif untuk Penelitian. Jakarta: RajaGrafindo Persada.

Sudijono, Anas. 2008. Pengantar Evaluasi Pendidikan. Jakarta: RajaGrafindo Persada.

Sudjana. 2005. Metode Statistika. Bandung: Tarsito

Sunarto dan Hartono, A. 2008. Perkembangan Peserta Didik. Jakarta: Rineka Cipta

Yudhanegara, M. R. dan Lestari, K. E. (2017). Penelitian Matematika. Bandung: Refika Aditama. 